\title{
Stock Market Development in Country With Least Development But Fast Economic Growth: A Case Study of Lao PDR*
}

\author{
Somvixay Chanthavong \\ Kyoto University, Kyoto, Japan
}

\begin{abstract}
This paper aims to examine the market development evolution of Lao Securities Exchange (LSX) by observing the institutional structure, securities regulations, and government's policy and utilizing the annual data of market indicators from 2011 to 2017 through the regression model in order to determine the facing issues with proposing the resolution implication for securities exchange development. The finding of this paper also concludes that the liquidity issue, small number of listed firms, undiversified products, small investor base, insufficient legislation from regulatory body, and slow progress in transforming state-owned enterprises (SOEs) into public companies are the current pressure obstacles for securities market development in Laos. In this case, there is a need for stronger commitment from government in securities market development by closer collaboration among line ministries, enlarging the investor base to public and private sectors, acknowledging the significance of drafting the public company act, and persuading the SOEs to issue initial public offering (IPO) in LSX, as the result would drive positive impacts to stimulate the capital market development in Lao People's Democratic Republic (Lao PDR).
\end{abstract}

Keywords: Lao Securities Exchange (LSX), Lao stock market, listing companies, financial system, capital market

\section{Introduction/Objectives and Goals}

Since 2016, the Association of Southeast Asian Nations (ASEAN) economy has been integrating across 10 member states. As a result, the economy of Lao PDR has grown at 7.02\% (2016) with average of GDP growth rate approximately 7\% over the last decade (Bank of the Lao PDR, 2016a), and the World Bank (2017) has marked Lao PDR as one of the fastest growing economies in the East Asia and Pacific region and the 13th fastest growing economy globally. This country has become the prominent destination for the business endeavors of foreign investors due to their low-cost labor and abundance of natural resources. One of the key drivers for retaining the economic growth in Laos is an effective financial management system, including the capital market.

\footnotetext{
* Acknowledgement and Legal Responsibility: This research was partially supported by the On-Site Education and International Collaboration Support Office, Graduate School of Asian and African Area Studies, Kyoto University, Japan for partial fund on fieldwork in Lao PDR from September 4, 2017 to October 30, 2017. I would like to express my sincere gratitude to Professor Fumiharu MIENO, economics professor and Deputy Director of Center for Southeast Asian Studies, Kyoto University, who supervised and provided insight recommendation to this research. I also extend my deep thanks to officers in Lao Securities Exchange, and all participants in the Asian Economic Development Seminar, and Research Seminar on Environment, Society and Culture, the classes of Professor Kosuke MIZUNO, and Professor Fumiharu MIENO, for sharing their pearls of wisdom and feedback during my oral presentation in the seminars.

Somvixay Chanthavong, Ph.D. candidate, Graduate School of Asian and African Area Studies, Kyoto University. Email: joysomvixay@gmail.com.
} 
As capital market was firstly introduced in 2010 after the establishment of LSX through joint venture between Bank of Lao PDR (BOL) 51\% and Korea Exchange 49\%, the financing amount in capital market has reached 5,960 billion LAK in 2016 (LSX, 2016). LSX assumes to contribute to Lao economic growth from the early stage as a means of providing fund raising source for companies, but the progress of market development is moving quite slow after observing the quantity measures. Most of local companies have been traditionally relying on the banks, reflecting to the equity market to remain only six listed firms in 2017. Therefore, this paper aims to examine the securities market development platform in Laos through synthesizing the institutional structure, regulations, and commitment from government for capital market development and investigating the major market indicators in order to present better perception on how the stock market develops in Laos and what the issues occur in this equity market with resolution implication for stock market development.

\section{Literature Review and Methodology}

Despite banking sector has contributed to the economic growth for long decades, many researchers are currently paying more attention to capital market field after the flourishing of stock market across the world due to high expectation of stock market distribution to long-term growth of the country. There are various academic articles recognizing that a well functioning of financial system is crucial to economic growth, especially the stock market. Stock market pays a significant role in driving economic growth in the long run, and many evidences prove this view. For instance, Demirguc-Kunt and Levine (1996), Singh (1997), Levine (1997), Levin and Zervos (1998), and Arestis, Demetriades, and Luintel (2001) supported that "stock market development plays an important role in predicting future economic growth". Thus, there are different approaches in investigating the stock market development, particularly Garcia and Liu (1999), which examined the stock market development from the macroeconomic approach by using the real income, savings rate, financial intermediary development, and the stock market liquidity to explain the determinants of market development; controversially, the institutional variables, remittances, are also explanatory variables in evaluating the stock market development as well (Billmeier \& Massa, 2007).

Following the fundamental perception of financial system development role in economic growth, Lao government has also improved the financial system simultaneously through consulting with international organizations, including the International Monetary Fund, World Bank, and Asian Development Bank for controlling the inflation rate and retaining the macroeconomic stability. The Lao financial system reform has been implemented since the 1980s, which initially emphasized banking sector reformation into market liberalization as a core sector of financial service. Moving to 2010, in responding to the regional integration and economic change, the LSX has been established with supporting from Korea Exchange accounting for $49 \%$ in joint venture with Lao government, represented by Bank of the Lao PDR. This turns out to be the breaking point of the first stock market commencement in Lao PDR. This market assumes to contribute to Lao economic growth in the early stage, but most of business firms are still relying on banking sector and have small portion of heavy industry in enterprise characteristics with tiny economic scale of Laos, and the LSX is gently developing compared to other markets in the region (based on the data from World Federation of Exchanges, 2017), which still requires a long time in catching up with the advanced countries at the point of listed firms as shown in Figure 1. 
Furthermore, there are extremely few researchers who have analyzed this small market, because they have limited information and restricted understanding of local context. Therefore, these critical characteristics inspired the author to synthesize this stock market by observing its product supply side, demand side, and core market indicators (see Figure 2).

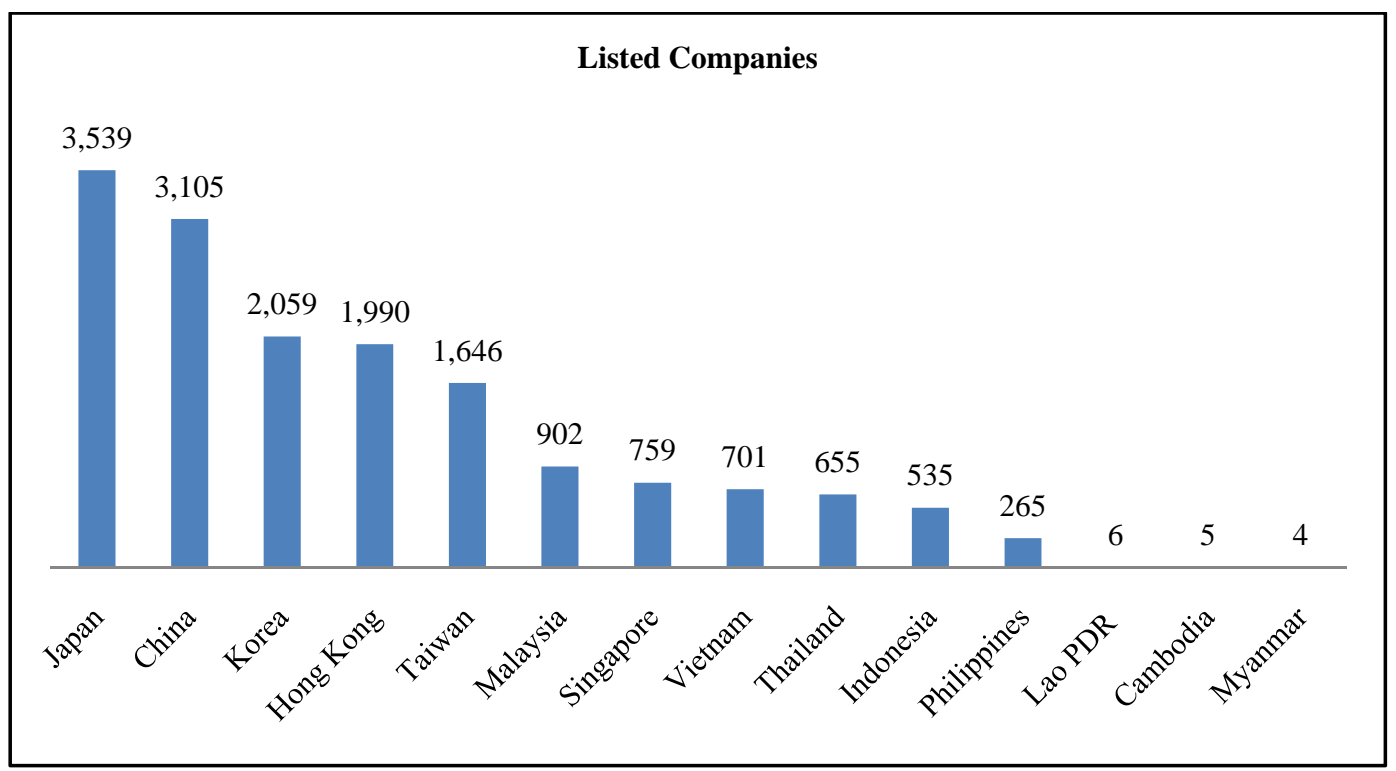

Figure 1. Number of listed companies in the region. Source: World Federation of Exchanges (2017).

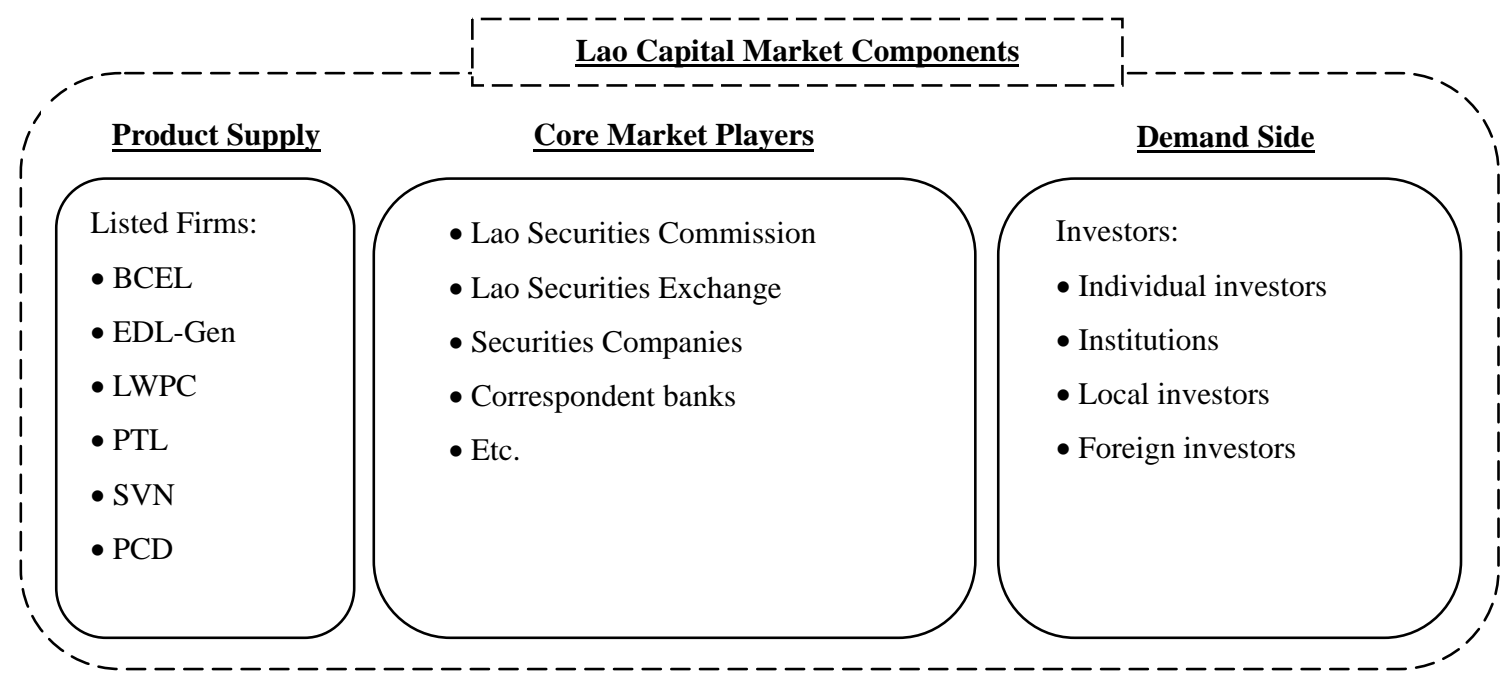

Figure 2. Lao capital market components.

Lao capital market is developed under three main components: (1) product supply: There are six listed firms at the end of 2017 and this will be described in detail in the later section; (2) core market players including Lao Securities Commission, LSX, securities companies, etc.; and (3) demand side: It is referred to the entire types of investors. This paper manages to investigate the product supply side and demand side and observe the market indicators of LSX to present the market development evolution and the occurred issues with resolution implication for stock market development. 
To maintain the quality of this paper, the author has done his fieldwork in Laos during September to October 2017 by visiting LSX and taking interview with management level and officers inside the stock market and other securities partners for better perception of local context and information collection. Then, the author applies the annual data of market indicators from 2011 to 2017 with regression model in describing the market situation and challenges and proposes possible resolution as conclusion of this paper.

\section{Results}

\section{Product Supply Side}

As of the end of 2017, in accordance with the listed company list (2017) from LSX, there are six listing firms in LSX, namely, Banque Pour Le Commerce Exterieur Lao Public Company (BCEL), EDL-Generation Public Company (EDL-Gen), Lao World Public Company (LWPC), Petroleum Trading Lao Public Company (PTL), Souvanny Home Center (SVN), and Phousy Construction and Development Public Company (PCD). This stock exchange appears to be a small market and develops slowly in terms of quality and quantity, as it has only two SOEs and four private firms listing in the market. As a result, two SOEs (BCEL and EDL-Gen) were pointed out to be the greatest and most prominent firms in the market, accounting for $80 \%$ of total dairy trading stocks. EDL-Gen is the biggest firm in terms of market size with $70 \%$ of total market capitalization, while BCEL, LWPC, PTL, SVN, and PCD are 10\%, 2\%, 5\%, 4\%, and 9\% respectively (see Table 1). In the process of SOEs transformation, there were reportedly 130 fully SOEs at the end of 2015, 42\% of which were operating at the central level and $32 \%$ of which were under the supervision of the Ministry of Finance ${ }^{1}$. But the number of listing SOEs in the stock market is only two firms, accounting for $1.5 \%$ of total SOEs. It indicates the slow progress of Lao government in transforming SOEs into public companies and increasing the listing companies following the Strategic Plan of Lao Capital Market Development 2016-2025 to have at least 25 listed companies in 2020 and 60 listed companies in 2025 (Lao Securities Commission Office, 2016).

Table 1

Listing Firms in LSX

\begin{tabular}{llllcr}
\hline Listing firms & Listed date & Business & Free float (\%) & $\begin{array}{l}\text { Foreign holding } \\
\text { limitation (\%) }\end{array}$ & $\begin{array}{l}\text { Market capitalization } \\
\text { (USD) }\end{array}$ \\
\hline BCEL & $2011-01-11$ & Finance & 20 & 20 & $141,511,498$ \\
EDL-Gen & $2011-01-11$ & Energy & 25 & 25 & $1,028,573,514$ \\
LWPC & $2013-12-25$ & Real estate & 10 & 100 & $31,154,215$ \\
PTL & $2014-12-09$ & Energy & 25.53 & 100 & $67,562,500$ \\
SVN & $2015-12-11$ & Construction materials 15.15 & 100 & $60,843,750$ \\
PCD & $2017-10-10$ & Construction service & 14.09 & 100 & $130,950,000$ \\
\hline
\end{tabular}

Notes. Source: LSX. " Author's circulation as market price on November 23, 2017; 1 USD = 8,000 LAK.

\section{Main Market Indicators}

Combining entire listed firms, the market capitalization of LSX is 1,496 million USD in 2017 covering 13\% of GDP, which has been doubled compared to the opening market period (see Figure 3). Although this market has been gradually developed and established after the flourishing of banking sector, the market capitalization to GDP still accounts for one-third of bank credit to GDP, which shows the significant improvement of capital market correlating to banking sector (see Figure 4).

\footnotetext{
${ }^{1}$ According to "Issues Paper - The corporate governance landscape and capital market development in Lao PDR", presented at the 3rd Meeting of the OECD-Southeast Asian Corporate Governance Initiative, June 1-2, 2016, Vientiane, Lao PDR.
} 
In spite of having better performance, the LSX has still been encountering with liquidity issue due to limited floating shares with insufficient portion of tradable shares on the market. As Duk Yun Lee, Chief Operating Officer of LSX, identified that "the tradable shares, which are available in the market, are restricted for investors to trade by excluding the total shares holders of top ten strategic partners, the percentage of tradable shares are only 8-13\% (in BCEL and EDL-Gen)”².

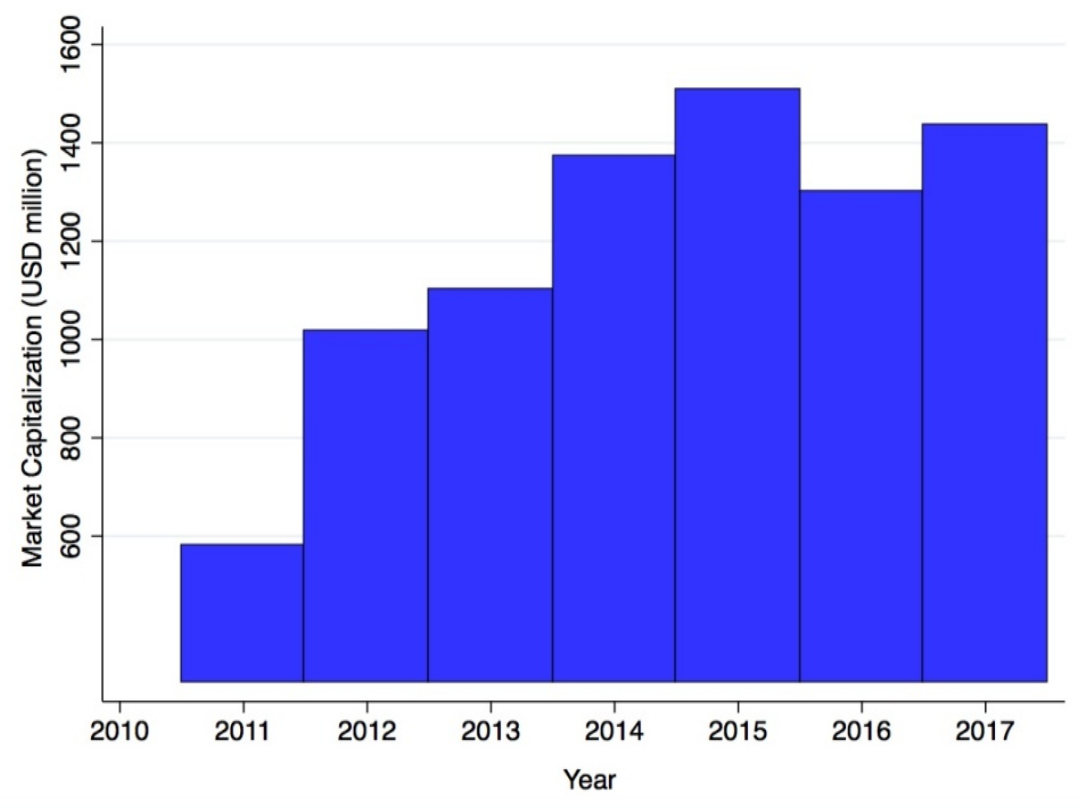

Figure 3. Market capitalization of LSX.

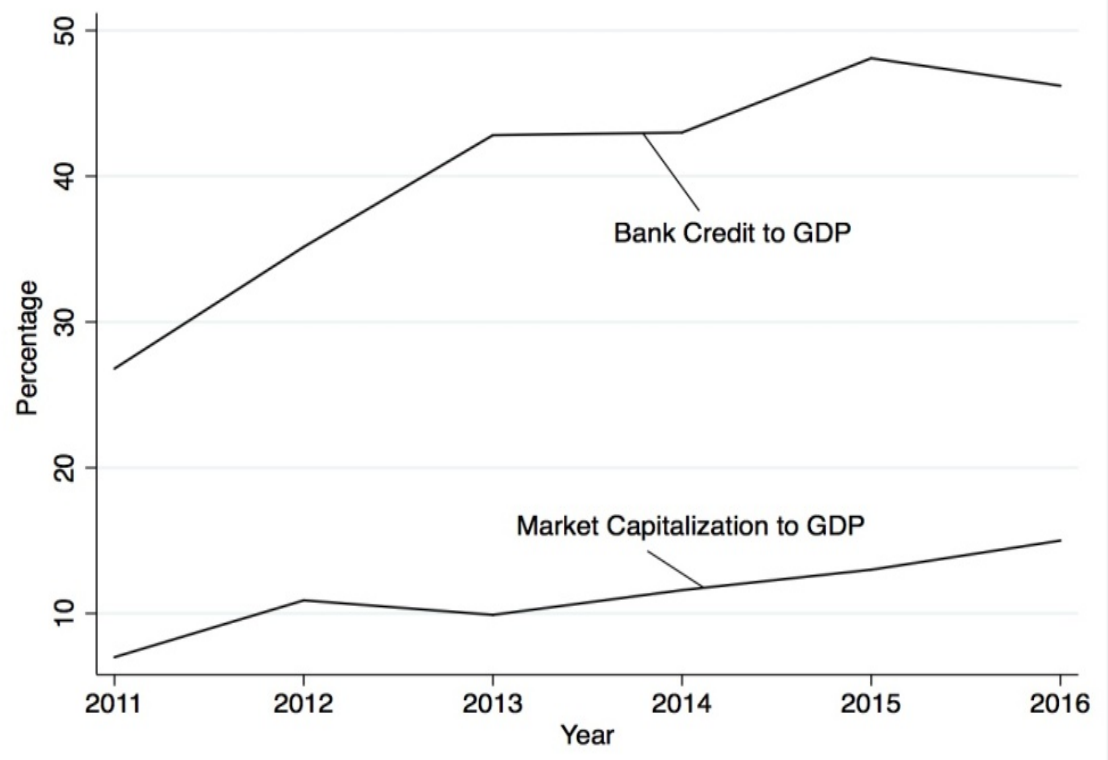

Figure 4. Market capitalization and bank credit to GDP. Source: LSX and Bank of the Lao PDR.

\footnotetext{
${ }^{2}$ Lao Stock Market Development (Personal interview, September 28, 2017).
} 
Though the LSX still has BCEL and EDL-Gen being the prominent and most traded stocks in the market, looking at their shares price over the earnings $(\mathrm{P} / \mathrm{E})$, shares price turns out to be underestimated in the market. Moreover, the average of value and volume traded are quite low (201.72 LAK million with 31,124,574 shares were traded annually). On the other hand, the ratio of total value traded to GDP, the measurement of valued securities transaction associates to economy, is only $0.4 \%$; while the ratio of total value traded to market capitalization, the measurement of valued securities transaction associates to the market size, is $2.5 \%$ as shown in Table 2. Both liquidity indicators explain the trading situation relating to size of economy and stock market.

Table 2

Summarized Statistics of VaT, VoT, MC/GDP, VaT/GDP, and VaT/MC (2011-2017)

\begin{tabular}{lllll}
\hline & Min. & Max. & Mean & Standard deviation \\
\hline VaT & 113.53 & 327.86 & 201.72 & 83.61 \\
VoT & $22,492,286$ & $47,989,800$ & $31,124,574$ & $9,537,362$ \\
MC/GDP $^{*}$ & 0.096 & 0.267 & 0.202 & 0.069 \\
VaT/GDP $^{* *}$ & 0.001 & 0.009 & 0.004 & 0.003 \\
VaT/MC & 0.011 & 0.065 & 0.025 & 0.019 \\
\hline
\end{tabular}

Notes. VaT = Value traded (LAK, billion); VoT = Volume traded (shares); MC/GDP = Market capitalization to GDP; VaT/GDP = Value traded to GDP; VaT/MC = Value traded to market capitalization. *, **: GDP is accounted from 2011-2016. Source: Author's calculation based on data from LSX and Bank of the Lao PDR.

Therefore, the LSX must take liquidity issue into account and urgently resolve this obstacle through closer coordination with partners in stimulating potential listing firms and blue chip companies for distributing IPO with more shares to the public and fostering the listed firms to implement broader international relation activities in order to assist investors' access to company information so that the liquidity issue can be recovered and absolved.

Following the core indicators of market performance, the regulation is also a key factor boosting capital market development and protecting investors. At present, the legislation, decrees, and regulations relevant to securities activities are enacted, particularly the Law on Securities, Enterprise Law, Listing Regulation, and Trading and Disclosure Regulation; however, the enterprise law has not yet been apparently classified on the function of listing companies, which is required to be amended and better managed. Moreover, the law on public companies, which could attract more listing firms to securities exchange if it is well explicated, has not yet been enacted in Laos. The Lao Securities Commission Office and LSX should recognize this essential legislation for better development of Lao capital market.

In responding to the market change, Lao government has declared the capital market promotion policy by diminishing $5 \%$ of income corporate tax (from $24 \%$ of income corporate tax payment into 19\%) for listing companies during initial listing period (four years) from the date of registration to stock market. For investor's side, the government also exempts the dividend tax and no capital gain tax for trading investors as well. Nevertheless, the capital market development is moving quite slow recently, but those policies are partially the positive signal of good recognition from government in market development.

\section{Demand Side}

When we observe from the demand side, the investors, who are registered and traded securities through LSX, have gently increased from 8,136 to 12,991 accounts (LSX, August 2017) rising approximately by $37 \%$ from the foundation year, and $80 \%$ of them are local investors as individual investor type (see Figure 5). This 
securities exchange assumes to be the most attractive destination for local investors, but the foreign investors, in point of fact, impress to be the most active investors who are in dairy trading, accounting for $80 \%$ among dairy trading investors if we realize the proportion of dairy trading by investor types (see Figure 6). These results have been a big influence on market trading volume; this trend indicates another challenge on the market volatility of LSX in consequence of much reliance on the foreign investors for dairy trading. The investor base is also small, the individual investor type consists of 99\%, and half of them are long-term investors. As Vanhkham Voravong, the Chief Executive Officer (CEO) of LSX recognized that:

Most of local investors have a tendency in purchasing the securities for long term investment, or keeping and waiting for dividend without active in securities trading. This might be depending on their weak awareness of securities trading benefits, and perception of capital market. ${ }^{3}$

Thus, the LSX is required to make more efforts to stimulate the initiative of local investors in dairy trading through disseminating and educating the local investors' trading skills with expanding the investor base to public and private sectors for sustainable development of securities exchange.

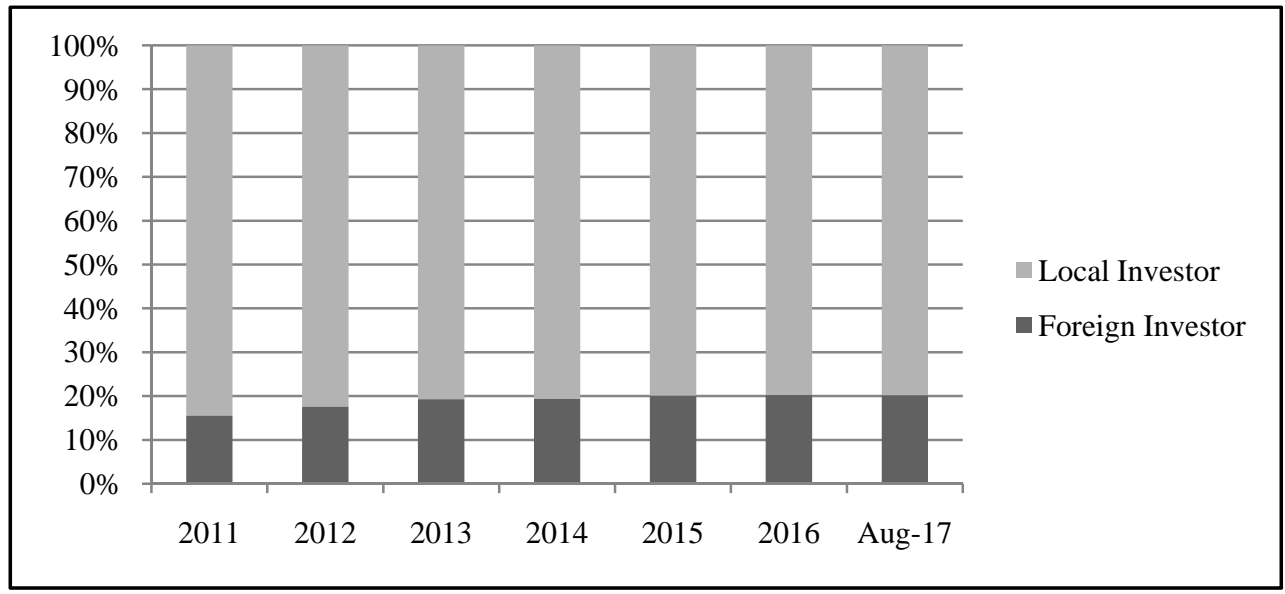

Figure 5. Number of securities account in LSX.

Source: Market Operation and Surveillance Department, LSX.

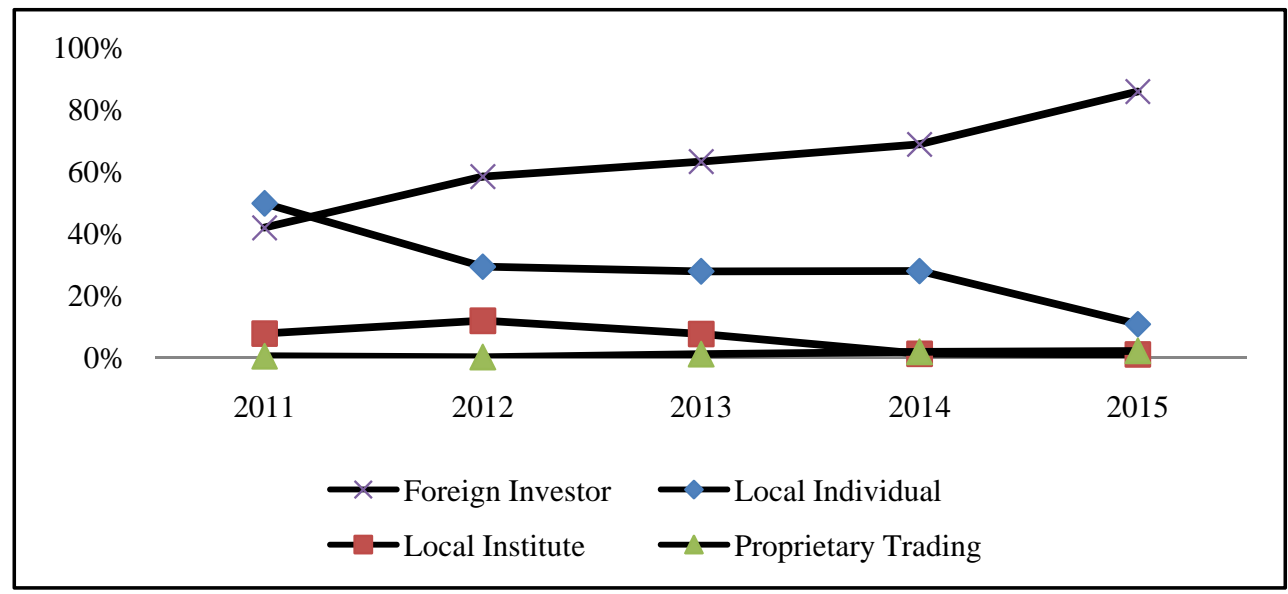

Figure 6. Dairy trading proportion by investor type.

Source: Market Operation and Surveillance Department, LSX.

${ }^{3}$ Lao Stock Market Development (Personal interview, September 28, 2017). 
One of the supporting characteristics for LSX to be competitive compared to other markets in the region is offering high rate of dividend yield from listing companies. The highest rate of dividend yield was $11.16 \%$ to market price in 2016 (dividend yield from BCEL, 2016) and the average rate of dividend yield (accumulated from entire listed firms) was around 3.87\% in 2016. This again shows that the BCEL and EDL-Gen are the most prominent firms in giving highest rate of dividend to investors annually. However, the fixed deposit rate in banking sector side is still given high rate as 5.72\% for one-year fixed deposit (BCEL, 2017) and it affects the local investors' behavior to better save their fund in the bank rather than investing in the equity market because of low risk in bank saving. It is worth nothing that the banking sector is currently playing a key role in both depository source and giving credit to companies, so it is not easy to smoothly develop equity market in Laos without the strong support from government and tight collaboration between securities bodies for adjusting the appropriate trend of financial system. Table 3 shows the comparative trend of the fixed deposit rate in the banking side (Bank of the Lao PDR, 2016b) and dividend yield given from the equity market.

Table 3

Fixed Deposit Rate and Dividend Yield From 2011 to 2016

\begin{tabular}{|c|c|c|c|c|c|c|c|}
\hline & & $2011(\%)$ & $2012(\%)$ & $2013(\%)$ & 2014 (\%) & 2015 (\%) & $2016(\%)$ \\
\hline \multirow{2}{*}{$\begin{array}{l}\text { Fixed deposit rate } \\
\text { (12 months) }\end{array}$} & Maximum & 12 & 10.25 & 10.05 & 10.75 & 8 & 5.72 \\
\hline & Mean & 8.95 & 8.62 & 8.90 & 8.60 & 7.59 & 5.43 \\
\hline \multirow{2}{*}{ Dividend yield } & Maximum & 10.67 & 9.95 & 9.24 & 7.92 & 7.84 & 11.16 \\
\hline & Mean & 10.15 & 8.49 & 8.64 & 4.60 & 3.77 & 3.87 \\
\hline
\end{tabular}

Note. Source: Bank of the Lao PDR (2016b) and LSX.

\section{Data}

In order to provide insight prescription of market development in Laos, the author utilizes the annual data of market indicators into regression model. The data consist of annual market capitalization accumulation over seven years from 2011 to 2017 as dependent variable; the author employs market capitalization for explaining the market development instead of market composite index because this proxy is not volatility as market composite index is. In addition, the core market indicators (including volume, value, investor account, and dividend yield) represent the independent variables (see Table 4).

Table 4

Variable Explanation

\begin{tabular}{lll}
\hline Variable & Type of variable & Variable unit \\
\hline Market capitalization & Dependent variable & LAK billion \\
Volume & Independent variable & Shares \\
Value & Independent variable & LAK billion \\
Investor account & Independent variable & Account \\
Dividend yield & Independent variable & $\%$ \\
\hline
\end{tabular}

\section{Regression Result}

Table 5 presents the simple correlation coefficients and $P$-value of variables. Comparing the independent variables of annual data from LSX suggests that the volume, value, and dividend yield are not correlated to the market capitalization as the market development explanation, or we can identify that the change in volume, 
value, and dividend yield has not yet responded to the market capitalization change in LSX during 2011-2017. There is only investor account that has defined the stock market development in Laos. Fundamentally speaking, this result confirms that the liquidity issue and small number of listed firms are huge obstacles leading to slow capital market development in Laos.

Table 5

Simple Correlation Coefficients and P-Value Result of Market Indicators (2011-2017)

\begin{tabular}{lcl}
\hline Variables & Coefficient & $P$-value \\
\hline Volume & -0.0000459 & 0.703 \\
Value & -9.270775 & 0.492 \\
Investor account & 1.107868 & 0.013 \\
Dividend yield & -844.4155 & 0.010 \\
\hline
\end{tabular}

\section{Conclusion}

In conclusion, LSX, from the practical standpoint, can be evaluated as having slow development based on its performance and Lao economy structure as a whole, and it can only achieve its goal in some extent after introduction for seven years. The securities exchange has obtained a visible result quantitatively, but we can hardly identify whether LSX has satisfied the needs of market participants timely and properly; there remains more room for LSX to be improved. Roughly speaking, the urgent obstacles should be considered by the Lao government and securities bodies, including the liquidity issue, small number of listed firms, undiversified products, small investor base, insufficient legislation from regulatory body, and slow progress in transforming SOEs into public companies. The indicated issues are the most essential remarks for securities parties to put more efforts in securities exchange development through closer collaboration with line ministries and private sectors, enlarging the investor base to public and private sectors, acknowledging the crucial role of drafting the public company act, and persuading the SOEs to list in LSX when they are ready to increase corporate governance and transparency of SOEs themselves.

\section{References}

Arestis, P., Demetriades, P. O., \& Luintel, K. B. (2001). Financial development and economic growth: The role of stock markets. Journal of Money, Credit and Banking, 33(1), 16-41. doi:10.2307/2673870

Bank of the Lao PDR. (2016a). Annual economic report 2016.

Bank of the Lao PDR. (2016b). Interest rate report 2016.

Banque Pour Le Commerce Exterieur Lao Public Company [BCEL]. (2017). Fixed deposit rate. Retrieved from http://www.bcel.com.la/bcel/?lang=en

Billmeier, A., \& Massa, I. (2007). What drives stock market development in the Middle East and Central Asia: Institutions, remittances or natural resources? Washington, DC: International Monetary Fund.

Demirguc-Kunt, A., \& Levine, R. (1996). Stock markets, corporate finance, and economic growth: An overview. The World Bank Economic Review, 10(2), 223-239. doi:10.1093/wber/10.2.223

Garcia, V. F., \& Liu, L. (1999). Macroeconomic determinants of stock market development. Journal of Applied Economics, 2(1), 29-59.

Lao Securities Commission Office. (2016). Strategic plan on Lao capital market development 2016-2025. Vientiane Capital: Lao Securities Commission Office, Bank of the Lao PDR.

Lao Securities Exchange [LSX]. (2016). Capital market development plan for liquidity improvement.

Lao Securities Exchange [LSX]. (2017). Listed companies list. Listing and Disclosure Department, LSX. 
Levine, R. (1997). Financial development and economic growth: Views and agenda. Journal of Economic Literature, 35(2), 688-726.

Levine, R., \& Zervos, S. (1998). Stock markets, banks, and economic growth. American Economic Review, 88(3), 537-558.

Singh, A. (1997). Financial liberalization, stock markets and economic development. The Economic Journal, 107(442), $771-782$.

The World Bank. (2017). Lao PDR overview. Retrieved from http://www.worldbank.org/en/country/lao

World Federation of Exchanges. (2017). Monthly report. WFE. Retrieved from https://www.world-exchanges.org/home/index.php/statistics/monthly-reports 